\title{
並列モデル同定を用いた多層建築物の部材損傷検出 MEMBER DAMAGE DETECTION OF MULTISTORY BUILDINGS USING PARALLEL MODEL IDENTIFICATION
}

\author{
濱本卓司*, 井上了太苂 \\ Takuji HAMAMOTO and Ryota INOUE
}

\begin{abstract}
A parallel model identification scheme is presented to detect member damage of multistory buildings. Three different mathematical models are used in the identification process : the frame model with member-end rotational springs for detecting member damage, the frame model with joint rotational springs for detecting joint damage and the flexural-shear lumped mass model for detecting story damage. The natural frequencies and mode shapes of a target building are identified from acceleration records measured at each story by ARX model. The changes in modal properties before and after damage events are used to define objective functions for each mathematical model. The objective functions are minimized to estimate the location and extent of story, joint and member damage, respectively, by simple genetic algorithm. The proposed scheme is applied to acceleration records of shaking table tests for different beam damage conditions. Based on the identification results, the usefulness and limitations of the proposed scheme are discussed.
\end{abstract}

Keywords : Parallel model identification, Member damage detection, Multistory building, Flexural-shear lumped mass model, Frame model with rotational spring, Genetic algorithm 並列モデル同定，部材損傷検出，多層建築物，質点系曲げせん断モデル，

回転ばね付きフレームモデル，遺伝的アルゴリズム

\section{1. 序}

振動モニタリングとシステム同定を組み合わせた損傷検出法はグ ローバルモニタリングの代表的手法である。この損傷検出法の特長 は，建物内に少数のセンサを配置して複数の低次モード特性を同定 し，損傷前後のモード特性の変化から損傷の位置と程度を推定でき る点にある。地震損傷を対象にした大型振動台実験により，層ごと に1つの加速度センサを設置すれば，質点系せん断モデルを用いる ことにより, 地震前後における低次の固有振動数変化から損傷層の 位置と損傷程度を推定できること ${ }^{1)}$, 地震作用時における低次の固 有振動数の時間変化から層損傷の進行状況を追跡できること采，が それぞれ確認されている。また，質点系ねじれ振動モデルを用いた $り^{3)}$ ，主に低次モードを励起する常時微動や地震動とともに，加振 機を建物内に設置して高次モードを励起するアクティブ同定手法を 導入したり することにより, 地震前後における固有振動数変化と モード形変化から, 損傷層を特定した後に損傷層内の損傷領域の位 置と損傷程度を推定する方法の有効性も実験的に確認されている。 しかし, 従来のシステム同定手法により実建物の部材損傷検出を行 うには，まだ多くの課題が残されている。

部材損傷検出を行いたい場合は，システム同定よりも損傷位置の 近くにセンサを直接設置するローカルモニタリングの方が有効であ
る。しかし，ローカルモニタリングでは，損傷の位置が初めからわ かっているわけではないため, 解析や実験あるいは経験的に損傷が 生じやすいと予想される位置, たとえば梁端や柱頭・柱脚などに多 数のセンサを分散配置しておく必要が生じる5)。

少数のセンサで層損傷検出を行うグローバルモニタリングを用い るか, 多数のセンサで部材損傷検出を行うローカルモニタリングを 用いるかの判断は, 損傷検出の目的に依存している。グローバルモ ニタリングでは, 数少ないセンサのデータから損傷に関する情報を 抽出せねばならず，全てのセンサのデー夕を一括処理することが必 要になる。一方, ローカルモニタリングでは, 膨大なセンサのデー 夕を迅速に処理して損傷に関する情報を抽出することが要求される ため, 各センサで最大值や累積值のような応答指標に変換しておき, それを相互比較して損傷を検出する分散処理が必要になる。現時点 では, グローバルモニタリングとローカルモニタリングの距離は隔 たっており，総合的なへルスモニタリング技術を確立する上で，両 者の隔たりを埋めることが求められている6)

こうした状況を背景に, 本研究では, グローバルモニタリングと ローカルモニタリングの中間的手法として, 各層に少数の加速度セ ンサを置いて部材損傷検出を行う並列モデル同定手法を提案する。 材端回転ばね付きフレームモデルを質点系曲げせん断モデルに変換

\footnotetext{
* 東京都市大学工学部建築学科 教授.工博

** 東電設計(株) 工修 （元 東京都市大学 大学院生） 
することにより，梁損傷が質点系モデルに適切に反映されるように した上で, 質点系曲げせん断モデルと実建物のモード特性の誤差を 最小化させるプロセスを通じて，材端回転ばね付きフレームモデル の剛性パラメターを推定する。材端回転ばね付きフレームモデルの パラメターの数は質点系曲げせん断モデルのパラメターの数よりは るかに多くなる。このため, 同一接合部に集まる部材の材端回転ば ねを一つに集約し，接合部での集約回転ばねの剛性変化を同定する ことにより損傷部材近傍の接合部の位置を特定した後, その接合部 に集まる各部材の材端回転ばねの剛性変化を個々に同定して部材損 傷検出を行う。既往の振動台実験の時系列データ占を用いて, 異な る梁端損傷に対して本手法を適用し，その有効性と適用限界を検討 する。

\section{2. 並列モデル同定}

本研究で提案する並列モデル同定とは，時系列モデルを用いて損 傷による対象構造物のモード特性の変化を同定した後，等価性を有 する複数の数学モデルを並列させ, 簡易モデルから詳細モデルへと 物理パラメターを順次推定する方法である。本研究では, 時系列モ デルとして ARX モデル, 数学モデルとして, 図1に示すように, 層剛性を物理パラメターとする質点系曲げせん断モデル，接合部で の集約回転ばね剛性を物理パラメターとする集約回転ばね付きフ レームモデル，および材端回転ばね剛性を物理パラメターとする材 端ばね付きフレームモデルを用いる。3つの数学モデルの等価性を 保証するために，材端回転ばね付きフレームモデルを基本モデルと して，それを縮約した集約回転ばね付きフレームモデル，さらに縮 約した質点系曲げせん断モデルを構築する。

3つの数学モデルは, 異なるレベルの損傷検出のために使用され る。図 2 に示すように, 質点系曲げせん断モデルは層レベルの損傷 検出のために用いる。損傷層が特定できたら, 集約回転ばね付きフ レームモデルを用いて，損傷部材が接続する接合部の位置を特定す る。損傷部材が接続する接合部が特定できたら，材端回転ばねモデ ルを用いて，損傷部材の位置を特定し損傷程度を推定する。すなわ ち、はじめに少数のセンサから得られる限定された情報を利用して 簡易モデルにより構造全体の状態を大まかに把握しておき, 徐々に 詳細化させたモデルに切り換えて損傷位置を絞り込む焦点化手法を 用いる。

しかし，詳細モデルになるほど未知パラメターの数は多くなり， 少数のセンサから得られる限定された情報から詳細モデルを同定す ることは困難になる。本研究では, 詳細モデルのパラメターの中で 剛性変化の生じない集約回転ばねあるいは材端回転ばねを既知パラ メターとして未知パラメターの数を低減し，限定された情報を詳細 モデルの同定に結びつける方法を試みる。図 3 に示すように, ARX モデルを用いて損傷による極と留数の変化を同定した後，対応する 質点系曲げせん断モデルの固有振動数とモード形の変化に変換し, その後の数学モデルの同定はモード空間で行う。損傷によるモード 特性の変化から数学モデルの物理パラメターの変化を推定する方法 は，モード同定に基づく損傷検出の標準的な手法である7)。質点系 曲げせん断モデルは全体構造が対象になるが，集約回転ばね付きお よび材端回転ばね付きフレームモデルは損傷領域として絞り込まれ た部分構造が対象になる。全体構造のモード特性の変化を引き起こ
す 2 つの部分構造の変化を推定するために, 質点系曲げせん断モデ

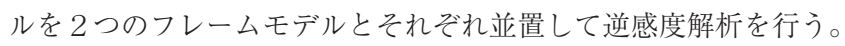

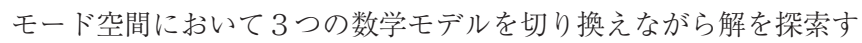
ることを考慮し, 最適化手法には物理パラメターを推定する際に柔 軟な対処が可能な遺伝的アルゴリズム ${ }^{8,9)}$ を用いる。

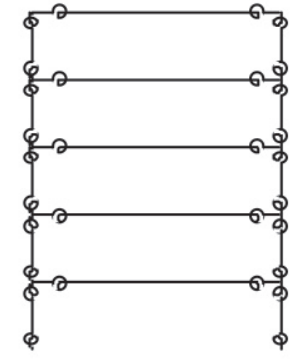

材端回転ばね付き フレームモデル

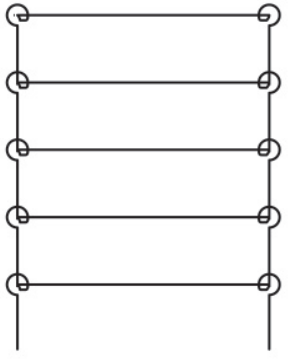

集約回転ばね付き フレームモデル

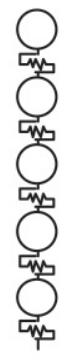

質点系曲げ せん断モデル
図1並列モデル同定に用いる $3 つ の$ 数学モデル

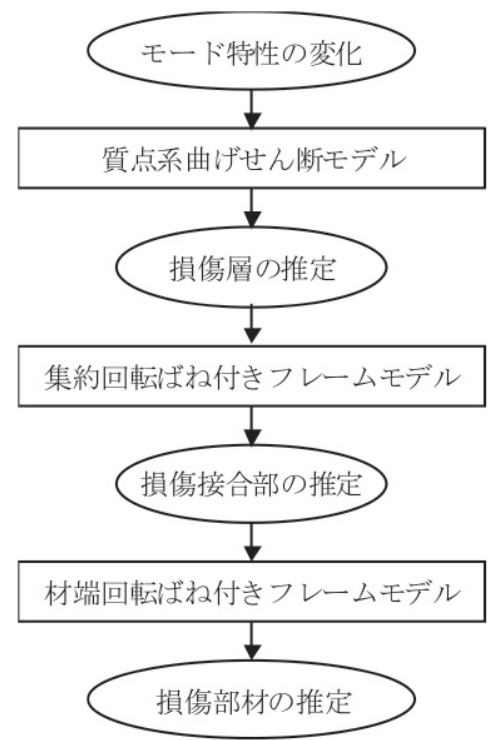

図2 並列モデルを用いた同定フロー

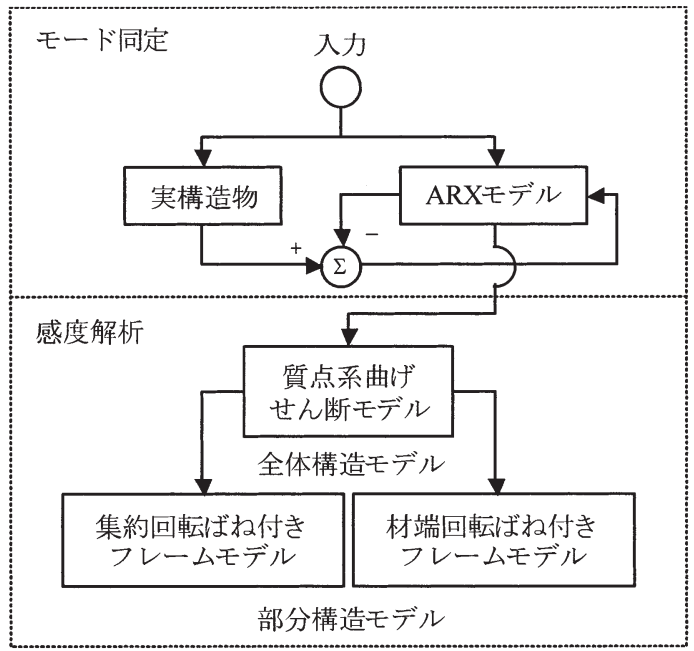

図３並列モデルを用いたシステム同定 


\section{3. 損傷検出のための数学モデル}

並列モデル同定に用いる $3 つ の$ 数学モデル，すなわち材端回転ば ね付きフレームモデル，集約回転ばね付きフレームモデル，および 等価曲げせん断モデルの関係を以下に示す。

\section{1 部材損傷検出のための材端回転ばね付きフレームモデル}

多層骨組構造物の地震損傷は, 梁端や柱頭・柱脚などの材端に生 じやすい。本研究では, 部材損傷検出のための数学モデルとして材 端回転ばね付きフレームモデルを用いる。梁材，柱材，および材端 回転ばねで構成される 2 次元モデルである。部材損傷を材端回転ば ねの剛性低下として評価し，ばね間の梁材と柱材については弾性変 形のみを考慮する。材端回転ばねの曲げ剛性は次式で与えられる ${ }^{10)} 。$

$$
k_{m}=\frac{\mu_{m}}{1-\mu_{m}} \cdot \frac{4 E I}{l}
$$

ここに, $E$ はヤング係数, $I$ は断面二次モーメント, $l$ は部材長さ, $\mu_{m}$ は柔性パラメターで，０のときピン接合，1のとき剛接合，下 添字 $m$ は部材番号を表している。部材の端部に損傷がないときは $\mu_{m}=1$, 損傷が生じると剛性が低下し $\mu_{m}$ の值は減少する。

材端回転ばねを有する梁材と柱材で全体骨組モデルを構成する と, 部材端で曲げとせん断に関する回転角と材軸直交方向変位の 2 自由度を有するので，全部材に関する剛性マトリクスのサイズは， $4 M \times 4 M$ になる。ここに， $M$ は部材数である。

\section{2 接合部損傷検出のための集約回転ばね付きフレームモデル}

部材損傷検出を行う前に, 損傷した材端部が結合する接合部の位 置を特定する。このために，材端回転ばね付きフレームモデルを集 約回転ばね付きフレームモデルに変換する。集約回転ばねの剛性は, 各接合部に集まる部材の材端回転ばね剛性の和として次式で与えら れる。

$$
k_{j}=\sum k_{m}
$$

上式は，接合部 $j$ に集まる部材 $m$ のすべての材端回転ばねを加算 することを表している。接合部で集約回転ばねを有するフレームモ

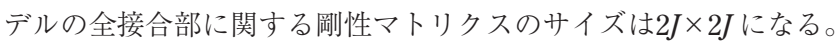
ここに,Jは接合部数である。

\section{3 層損傷検出のための質点系曲げせん断モデル}

層損傷検出には, 通常, 梁の変形を無視した質点系せん断モデル が用いられる。この場合, 梁端部の損傷は柱頭・柱脚の拘束を弱め

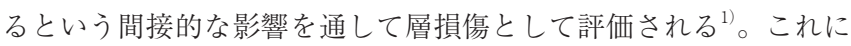
対し, 本研究では, 梁端部の損傷を直接反映できる質点系曲げせん 断モデルを用いる。材端回転ばね付きフレームモデルと質点系曲げ せん断モデルの等価性を保証するために，以下の手順でフレームモ デルから質点系モデルに変換する。

材端回転ばね付きフレームモデルから集約回転ばね付きフレーム モデルに変換した後, 集約回転ばね付きフレームモデルに静的縮約 をかけて回転角を消去する。このとき剛性マトリクスのサイズは $J$

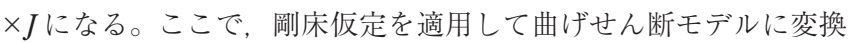
する。剛性マトリクスは $S \times S$ のフルマトリクスとなる。ここに， $S$ は層数である。最後に，八ウスホルダー変換により曲げを考慮し た等価せん断モデルに変換する。剛性マトリクスのサイズは $S \times S$ のままで三重対角化されるので, 質点系せん断モデルと同様に層剛 性に変換できる。

\section{4. 損傷指標の定義}

部材損傷検出を行う過程で用いた 3 つ数学モデルに対応して 3 つの損傷指標を定義する。質点系曲げせん断モデルでは層損傷指標， 集約回転ばね付きフレームモデルでは接合部損傷指標，材端回転ば ね付きフレームモデルでは部材損傷指標をそれぞれ用いる。

\section{1 層損傷指標}

損傷部材の影響を受ける層の位置の特定と損傷程度を評価するた めに層損傷指標を定義する。層損傷指標は, 損傷による層の剛性低 下を損傷前の層剛性で除した層剛性低下率として次式で与えられ る。

$$
\alpha_{s}=\frac{\Delta k_{s}}{k_{s 0}}=\frac{k_{s 0}-k_{s D}}{k_{s 0}}
$$

ここに， $\alpha_{s}$ は $s$ 層の層剛性低下率， $\Delta k_{s}$ は損傷前後の層剛性の差， $k_{s 0}$ と $k_{S D}$ はそれぞれ損傷前と損傷後の層剛性である。

\section{2 接合部損傷指標}

損傷部材の影響を受ける接合部の位置の特定と損傷程度を評価す るために接合部損傷指標を定義する。接合部損傷指標は, 損傷によ る集約回転ばねの剛性低下を損傷前の集約回転ばね剛性で除した接 合部剛性低下率として次式で与えられる。

$$
\beta_{j}=\frac{\Delta k_{j}}{k_{j 0}}=\frac{k_{j 0}-k_{j D}}{k_{j 0}}
$$

ここに, $\beta_{j}$ は接合部 $j$ の集約回転ばね剛性低下率, $\Delta k_{j}$ は損傷前後 の集約回転ばね剛性の差, $k_{j 0}$ と $k_{j D}$ はそれぞれ損傷前と損傷後の集 約回転ばね剛性である。

\section{3 部材損傷指標}

損傷部材の位置の特定と損傷程度を評価するために部材損傷指標 を定義する。部材損傷指標は, 損傷による材端回転ばねの剛性低下 を損傷前の材端回転ばね剛性で除した部材剛性低下率として次式で 与えられる。

$$
\gamma_{m}=\frac{\Delta k_{m}}{k_{m 0}}=\frac{k_{m 0}-k_{m D}}{k_{m 0}}
$$

ここに, $\gamma_{m}$ は部材 $m$ の材端回転ばね剛性低下率, $\Delta k_{m}$ は損傷前後 の材端回転ばね剛性の差, $k_{m 0}$ と $k_{m D}$ はそれぞれ損傷前と損傷後の 材端回転ばね剛性である。

\section{5. 損傷同定}

並列モデル同定における損傷同定のプロセスを以下に示す。

\subsection{ARX モデルによるモード同定}

各層に設置したセンサで計測された加速度時系列に ARX モデル を適用して実建物の固有振動数とモード形を同定する。各層で振動 を計測しているので, 同定されたモード形は質点系曲げせん断モデ ルに対応していることになる。同定されたモード特性の損傷前後で の変化に着目して，固有振動数変化率とモード形変化率をそれぞれ 以下のように定義する。

固有振動数変化率は, 損傷前後における固有振動数の二乗の変化 率として次式により求める。

$$
\Delta \Omega_{n}=\frac{\omega_{0 n}^{2}-\omega_{D n}^{2}}{\omega_{0 n}^{2}}
$$

ここに, $\omega_{0 n}$ と $\omega_{D n}$ はそれぞれ損傷前と損傷後の $n$ 次固有円振動数 である。損傷がないと固有円振動数の変化はないので 0 となる。 
モード形変化率は，損傷前後におけるモード形の MAC（Mode Assurance Criterion）值を利用して次式により定義する。

$$
\Delta \Psi_{n}=1-\frac{\left|\left\{\varphi_{0 n}\right\}^{T}\left\{\varphi_{D n}\right\}\right|^{2}}{\left\{\varphi_{0 n}\right\}^{T}\left\{\varphi_{0 n}\right\}\left\{\varphi_{D n}\right\}^{T}\left\{\varphi_{D n}\right\}}
$$

ここに, $\left\{\varphi_{0 n}\right\}$ と $\left\{\varphi_{D n}\right\}$ はそれぞれ損傷前と損傷後の $n$ 次モード形 である。損傷がないとモード形の変化はないので 0 となる。

\section{2 質点系曲げせん断モデルによる層損傷同定}

各層に 1 台の加速度センサを配置した場合，通常は層レベルの損 傷検出しかできない。これは, 各層 1 自由度の質点系せん断モデル を用いてシステム同定を行うことによる限界である。柱に損傷が生 じた場合，層剛性低下を直接引き起こすため，質点系せん断モデル でも比較的容易に損傷検出が可能である。しかし，梁に損傷が生じ た場合，梁の損傷が柱の材端拘束を弱めるという間接的な影響で層 剛性低下を引き起こすことになるため, 層剛性低下は小さくなり損 傷検出が難しくなる。実際, 文献 1 ) では, 柱の損傷はすべて精度 良く同定できているものの, 梁の損傷になると損傷同定の精度が落 ち，中間層の梁損傷は同定できないケースも見られた。

本研究では，梁損傷の影響を直接的に評価する質点系曲げせん断 モデルを用いる。ARX モデルで同定した実建物のモード特性の変 化を質点系曲げせん断モデルの物理パラメターの変化に適合させる ために，以下の目的関数を用いる。

$$
F_{s}=\sum_{n=1}^{N F} c_{n}\left|\Delta \Omega_{n}^{L}\left(\alpha_{s}\right)-\Delta \Omega_{n}^{R}\right|+\sum_{n=1}^{N S} d_{n}\left|\Delta \Psi_{n}^{L}\left(\alpha_{s}\right)-\Delta \Psi_{n}^{R}\right|
$$

ここに, $c_{n}$ と $d_{n}$ は $n$ 次の固有振動数とモード形の選択パラメター （選択するとき 1 ， しないとき 0 ）， $\Delta \Omega_{n}^{L}\left(\alpha_{s}\right)$ と $\Delta \Omega_{n}^{R}\left(\alpha_{s}\right)$ はそれぞれ 質点系曲げせん断モデルと実建物の固有振動数変化率, $\Delta \Psi_{n}^{L}$ と $\Delta \Psi_{n}^{R}$ はそれぞれ質点系曲げせん断モデルと実建物のモード形変化率, $N F$ と NS はそれぞれ固有振動数とモード形の数である。

$F_{s}$ を最小化することにより, 損傷前後に掞ける層の剛性低下率 $\alpha_{s}$ を同定し，損傷層の位置と損傷程度を推定する。

\section{3 集約回転ばね付きフレームモデルによる接合部損傷同定}

集約回転ばね付きフレームモデルと質点系曲げせん断モデルの モード特性の変化を適合させて, 集約回転ばね付きフレームモデル の物理パラメターの変化を推定するために以下の目的関数を最小化 する。

$$
F_{j}=\sum_{n=1}^{N F} c_{n}\left|\Delta \Omega_{n}^{J}\left(\beta_{j}\right)-\Delta \Omega_{n}^{L}\right|+\sum_{n=1}^{N S} d_{n}\left|\Delta \Psi_{n}^{J}\left(\beta_{j}\right)-\Delta \Psi_{n}^{L}\right|
$$

ここに, $\Delta \Omega_{n}^{J}\left(\beta_{j}\right)$ は集約回転ばね付きフレームモデルの固有振動数 変化率, $\Delta \Psi_{n}^{J}\left(\beta_{j}\right)$ は集約回転ばね付きフレームモデルのモード形変 化率である。

$F_{j}$ を最小化することにより，損傷前後における集約回転ばねの剛 性低下率 $\beta_{j}$ を同定し，損傷部材が結合する接合部の位置と損傷程 度を推定する。

\section{4 材端回転ばね付きフレームモデルによる部材損傷同定}

材端回転ばね付きフレームモデルと質点系曲げせん断モデルの モード特性の変化を適合させて, 材端回転ばね付きフレームモデル の物理パラメターの変化を推定するために以下の目的関数を最小化 する。

$$
F_{m}=\sum_{n=1}^{N F} c_{n}\left|\Delta \Omega_{n}^{M}\left(\gamma_{m}\right)-\Delta \Omega_{n}^{L}\right|+\sum_{n=1}^{N S} d_{n}\left|\Delta \Psi_{n}^{M}\left(\gamma_{m}\right)-\Delta \Psi_{n}^{L}\right|
$$

ここに, $\Delta \Omega_{n}^{M}\left(\gamma_{m}\right)$ は材端回転ばね付きフレームモデルの固有振動 数変化率, $\Delta \Psi_{n}^{M}\left(\gamma_{m}\right)$ は材端回転ばね付きフレームモデルのモード 形変化率である。

$F_{m}$ を最小化することにより，損傷前後における材端回転ばねの 剛性低下率 $\gamma_{m}$ を同定し, 損傷部材の位置と損傷程度を推定する。

\section{6. 遺伝的アルゴリズムによるパラメター推定}

式(8)〜(10)の目的関数を最小化するための最適化手法として遺伝的 アルゴリズムを用いる。アルゴリズムのフローを図4 に示す。損傷 指標としての剛性低下率を 2 進数表現での遺伝子列として表し, 規 定した個体数の遺伝子をランダムに発生させた後, 各個体の適合度 を求めランク付けをする。高ランクの個体をエリートとして確保し, 残りの個体にルーレット選択を適用し, 各個体の適合度に比例した 残存機会を与える。交叉プールの中で親の選択をし, 選ばれたペア 同士で一点交叉を行う。その後に少数の遺伝子を突然変異させ, 設 定した世代数だけ同じ手順を繰り返す。本研究では, 個体遺伝子表 現は16bit の 2 進数表現とし, 個体数1000, エリート選択率15\%, 交差確率 $80 \%$, 突然変異率 $1 \%$, 評価回数 3000 世代とした。

式(8)では, 質点系曲げせん断モデルと実建物のモード特性変化が 一致するような層剛性低下率の最適解を求めるために遺伝的アルゴ リズムを適用する。式(9)では, 集約回転ばね付きフレームモデルと 質点系曲げせん断モデルのモード特性変化が一致するような集約回 転ばね剛性低下率の最適解を求めるために遺伝的アルゴリズムを適 用する。式(10)では，材端回転ばね付きフレームモデルと質点系曲げ せん断モデルのモード特性変化が一致するような材端回転ばね剛性 低下率の最適解を求めるために遺伝的アルゴリズムを適用する。

最適值への収束を示す指標として, 式(8)〜(10)の目的関数を用いて 以下の適合関数を定義する。

$$
\text { Fitness }=\frac{1}{1-F}
$$

ここに，Fは一般的な目的関数を表わし，式(8)を用いるときは $F_{s}$, 式(9)を用いるときは $F_{j}$, 式(10)を用いるときは $F_{m}$ となる。

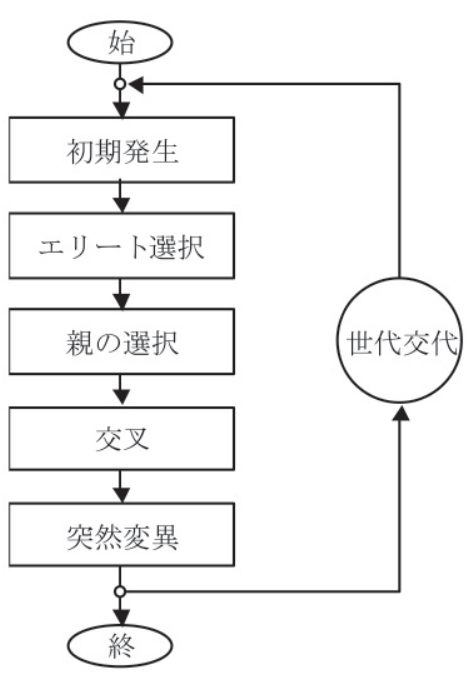

図4 遺伝的アルゴリズムのフロー 


\section{7. 同定結果と検討}

\section{1 振動台実験の概要}

本手法の有効性と適用限界を検討するために, 文献 1 ）と同じく, 図 5 に示す 5 層鋼製フレームの振動台実験において計測された各層 での加速度時系列デー夕を用いる。振動台での入力は $0 \sim 200 \mathrm{~Hz}$ の 帯域限定ホワイトノイズである。柱部材の損傷に関しては，通常の 質点系せん断モデルを用いた同定で十分精度が得られているので, ここでは表 1 のよに，質点系せん断モデルでは同定精度が十分で はなかった梁部材の端部損傷に関する実験データのみを使用する。 無損傷状態に対する実験を行った後, 損傷状態として, (1)梁の左フ ランジ継手を除去した場合（BS1，BS3，BS5），(2)梁左端部に切り 欠きを入れた場合 $(\mathrm{BC} 1, \mathrm{BC} 3, \mathrm{BC} 5)$, (3)梁の左フランジ継手の ボルトを緩めた場合（BB1，BB5）の 3 パターンの模擬損傷が設定 された。

\subsection{ARX モデルによるモード特性の同定}

計測された加速度時系列データに ARX モデルを適用して， 1 〜 5 次の固有振動数とモード形を同定する。ARX モデルの次数は, 残差が 0 近傍に十分収束する35次とした。ARX モデルにより同定 された無損傷状態における固有振動数と減衰比を表 2 に示す。

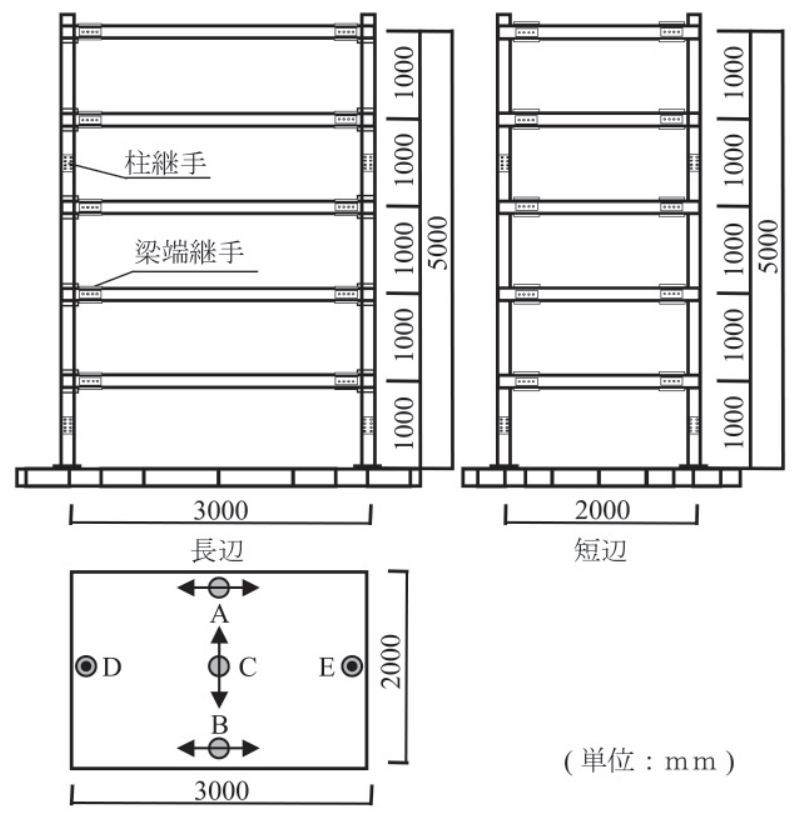

図 5 実験模型
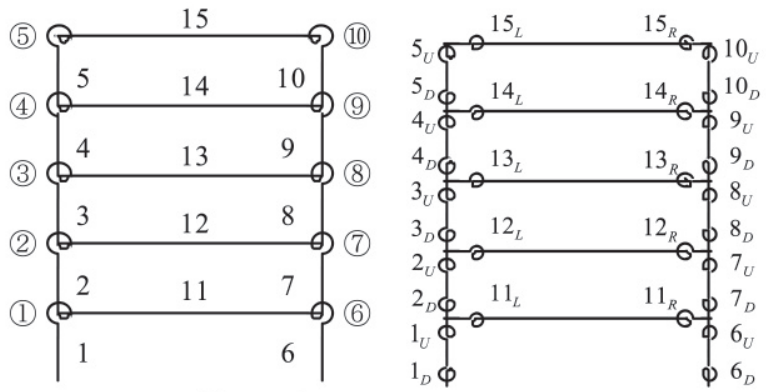

$m:$ 部材番号 (j) : 接合部番号

(b) 材端ばね番号

\section{3 質点系曲げせん断モデルの精度}

5 層の鋼製フレームの部材番号，接合部番号，材端回転ばね番号 を図 6 に示す。無損傷状態において，質点系曲げせん断モデルと質 点系せん断モデルを ARX モデルの結果にフィッティングさせた後, 固有值解析により求めた固有振動数を表 2 に示す。質点系せん断モ デルでは高次モードになると精度が落ちるが, 質点系曲げせん断モ デルでは，4，5次に扔いても誤差が $4 \%$ 以内にとどまっている。 計測データにARX モデルを適用して同定したモード形と固有值解 析により求めた各モデルのモード形を図 7 に示す。1～3 次では質

表 1 損傷パターンの設定

\begin{tabular}{l|c}
\hline 損傷パターン & 損傷箇所 \\
\hline BS1（1 層梁左端フランジ継手除去） & 1 層 \\
BS3（3 層梁左端フランジ継手除去） & 3 層 \\
BS5（5 層梁左端フランジ継手除去） & 5 層 \\
\hline BC1（1 層梁左端切欠き） & 1 層 \\
BC3（3 層梁左端切欠き） & 3 層 \\
BC5（5 層梁左端切欠き $)$ & 5 層 \\
\hline BB1（1 層梁左端継手ボルト緩め) & 1 層 \\
BB5（5 層梁左端継手ボルト緩め) & 5 層 \\
\hline
\end{tabular}

表 2 無損傷状態における固有振動数の比較

\begin{tabular}{c|c|c|c|c}
\hline \multirow{2}{*}{$\begin{array}{c}\text { モード } \\
\text { 次数 }\end{array}$} & \multicolumn{4}{|c}{ モデル } \\
\cline { 2 - 5 } & $\begin{array}{c}|c| \\
\text { ARX 固有振動数 } \\
(\mathrm{Hz})\end{array}$ & 減衰比 & $\begin{array}{c}\text { 固有振動数 } \\
(\mathrm{Hz})\end{array}$ & $\begin{array}{c}\text { せ固有振動数 } \\
(\mathrm{Hz})\end{array}$ \\
\hline 1 & 2.91 & 0.0030 & 2.95 & 2.97 \\
\hline 2 & 8.85 & 0.0011 & 8.92 & 8.78 \\
\hline 3 & 14.82 & 0.0010 & 15.10 & 14.21 \\
\hline 4 & 20.33 & 0.0008 & 20.74 & 18.73 \\
\hline 5 & 24.40 & 0.0007 & 25.19 & 21.74 \\
\hline
\end{tabular}
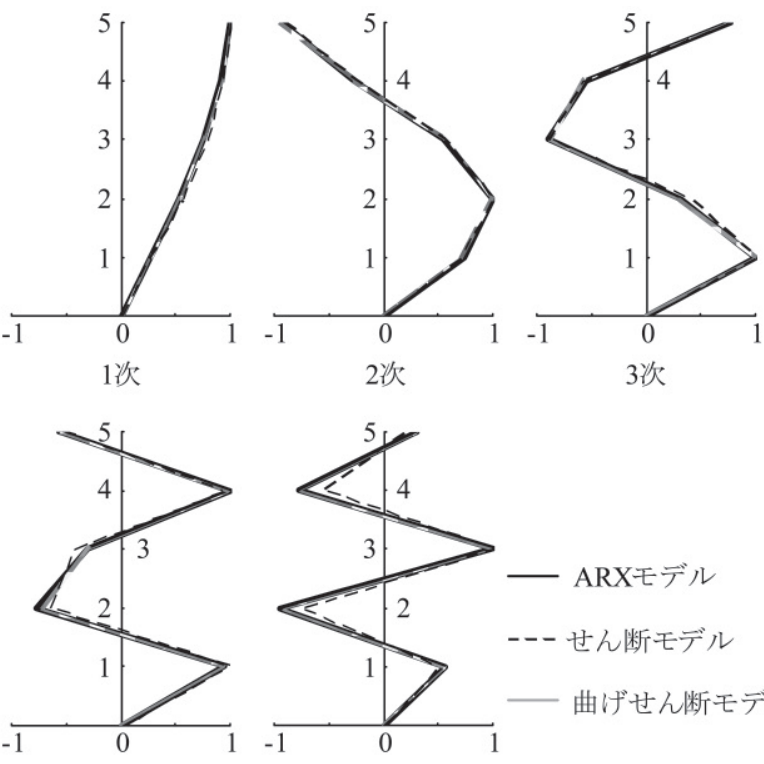

5次

図 7 無損傷状態におけるモード形の比較 
表 3 同定のための採用モード次数

\begin{tabular}{c|c|c|c}
\hline \multirow{2}{*}{ 選択モード } & 損傷状態 & $\begin{array}{c}\text { 固有振動数 } \\
\text { 変化率 }\end{array}$ & $\begin{array}{c}\text { モード形 } \\
\text { 変化率 }\end{array}$ \\
\hline 1 & 全状態 & $1 \sim 5$ 次 & なし \\
\hline \multirow{2}{*}{3} & 全状態 & $1 \sim 5$ 次 & $1 \sim 5$ 次 \\
\hline \multirow{5}{*}{3} & BS1 & 1,2 次 & $1,2,5$ 次 \\
& BS3 & $1,2,4$ 次 & $2,3,4$ 次 \\
\cline { 2 - 5 } & BS5 & $2,3,4$ 次 & $3,4,5$ 次 \\
\hline & BC3 & $1,2,3,4$ 次 & 3 次 \\
& BC5 & $1,2,3,4$ 次 & 3,4 次 \\
\cline { 2 - 5 } & BB1 & $1,2,3$ 次 & なし \\
& BB5 & $1,2,3,4$ 次 & 4 次 \\
\hline
\end{tabular}

点系曲げせん断モデルと質点系せん断モデルの差はほとんどない が， 4, 5 次のモード形振幅は中間層部分において質点系曲げせん 断モデルの方がARX モデルとの一致度は良い。1〜3 次のみを用 いて同定を行う場合はせん断モデルでも良いが，4，5次を含めて 同定を行う場合は曲げせん断モデルを用いる必要がある。Saito et $a l .{ }^{11)}$ も同じ振動台実験を対象とした層損傷検出の際に，質点系せん 断モデルの適用限界を指摘している。

\section{4 同定のための選択モード}

各損傷パターンの同定に用いる固有振動数変化率とモード形変化 率のモード次数の選択を表 3 に示す。選択モード 1 は固有振動数変 化率に関しては全モードを使用し，モード形変化率に関しては全 モードとも使用しない場合である。選択モード 2 は固有振動数変化 率とモード形変化率ともに全モードの情報を使用する場合である。 選択モード 3 では, 固有振動数変化率とモード形変化率のそれぞれ において, 固有振動数変化率とモード形変化率の最大のモードを基 準として, 各変化率の $1 / 3$ を下回るモードを除去した場合, すなわ ち感度の低いモードをノイズ混入の原因と見て除去した場合であ る。

\section{5 遺伝的アルゴリズムの収束状況}

遺伝的アルゴリズムによる目的関数の最小化過程を, 梁端フラン ジ継手除去の場合を例として，選択モード 3 における層損傷，接合 部損傷，部材損傷それぞれの場合について図 8 に示す。エリートと 母集団平均の収束を併せて示した。層損傷の同定では, BS1と BS5 は100世代と収束は速く, 中間層損傷の BS3は世代数800でようやく
収束している。接合部損傷の同定では, BS1は400世代を要し, BS3 と BS5は 100 世代と比較的早く収束している。部材損傷の同定では, BS1と BS5で100世代, 中間層損傷の BS3では500世代を要している。

\section{6 梁端フランジ継手を除去した場合の部材損傷検出}

梁端フランジ継手を 1 層 (BS1)，３層（BS3），５層（BS5）で 除去した場合の層損傷，接合部損傷，および部材損傷を同定する。

ARX モデルにより同定した固有振動数変化率を図 9 に, モード 形変化率を図10に示す。選択モード 3 に扔いて, 固有振動数変化率 とモード形変化率の採用モード次数は, 表 3 に示すように, それぞ れ BS1で 1, 2 次と 1,2,5 次, BS3で 1, 2, 4 次と 2, 3, 4 次, BS5で 2, 3,4 次と 3, 4, 5 次となった。

選択モード 1 〜 3 を用いて同定した層剛性低下率を図11に示す。 選択モード 1 〜 3 ともに, BS1では 1 層と 2 層, BS3では 3 層と 4 層, BS5では 5 層が損傷したと判別できる。層損傷の判別は, 剛性低下 率が負側に出たものと最大変化率の $1 / 3$ を下回るものを無損傷とみ なすことを基本とした。したがって，損傷接合部と考えられるのは BS1で接合部(1)か(6), BS3で接合部(3)か(8), BS5で接合部(5)か(10)の いずれかになる。

集約回転ばね付きフレームモデルにより同定した接合部剛性低下 率を図12に示す。損傷層が特定されたとき，選択モード 1 と 3 は, BS1で接合部(1), BS3で接合部(3), BS5で接合部(5)が損傷したと判 別できるが, 選択モード 2 は, 中間層損傷の BS3において損傷接合 部の判別ができない。接合部損傷の判別は, 剛性低下率が最大変化 率の $1 / 3$ を下回るものを無損傷とみなすことを基本とした。

材端回転ばね付きフレームモデルにより同定した部材剛性低下率 を図13に示す。損傷接合部が特定されたとき，選択モード 3 は， BS1で部材11，BS3で部材13, BS5で部材15が損傷したと明確に判 別できるが，選択モード 1 と 2 は BS3で判別しづらい。部材損傷の 判別は, 剛性低下率が最大変化率の $1 / 2$ を下回るものを無損傷とみ なすことを基本とした。選択モード 3 の部材剛性低下率は BS1 3 で0.4〜0.5の範囲で同定されているが, 選択モード 1 と 2 では同定 值のばらつきがやや大きい。

\section{7 梁端に切り欠きを入れた場合の部材損傷検出}

梁端の切り欠きを 1 層 $(\mathrm{BC} 1), 3$ 層 (BC3), 5 層（BC5）に入 れた場合の層損傷，接合部損傷，および部材損傷を同定する。

$\mathrm{ARX} モ テ ゙ ル に よ り$ 同定した固有振動数変化率を図14に, モード 形変化率を図15に示す。モード形変化率は, BC1で全モードに, $\mathrm{BC} 3$ で 2,3 次以外に, BC5で $3,4,5$ 次以外にそれぞれ有意な変 化が見られなかった。選択モード 3 に扔いて, 固有振動数変化率と

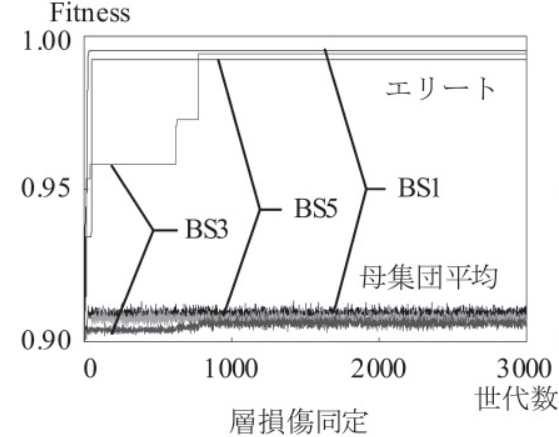

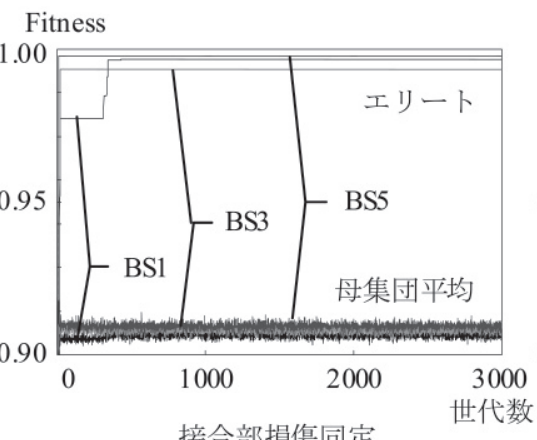

接合部損傷同定

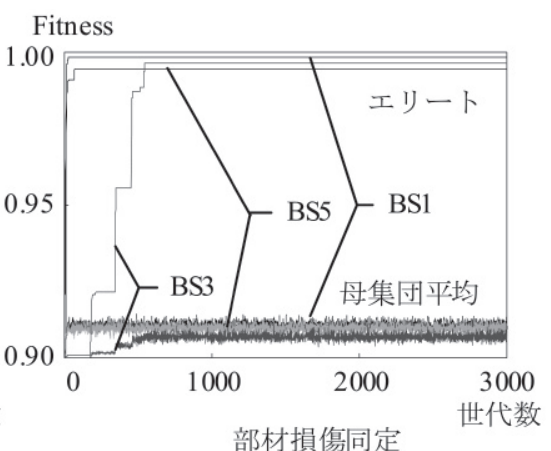

部材損傷同定

図 8 遺伝的アルゴリズムの収束状況 


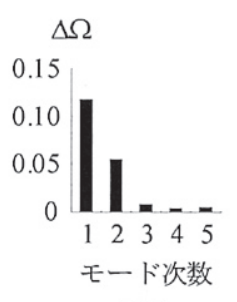

BS1
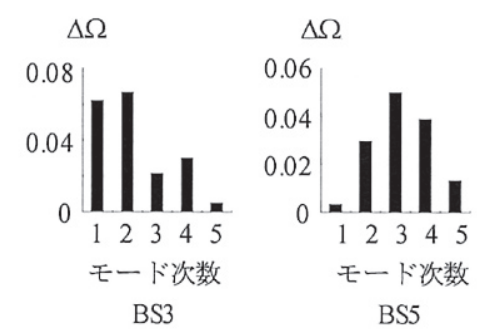

図 9 梁端フランジ除去の固有振動数変化率

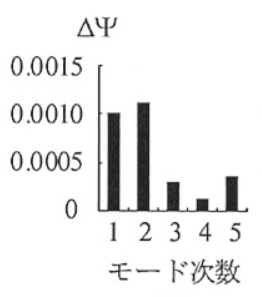

BS1
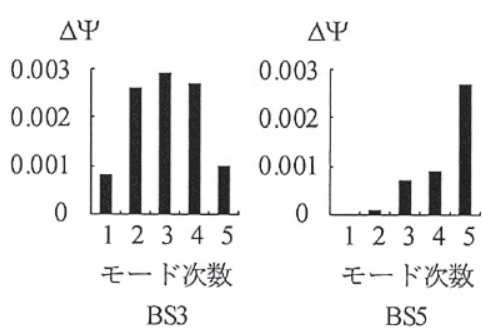

BS5

図10 梁端フランジ除去のモード形変化率

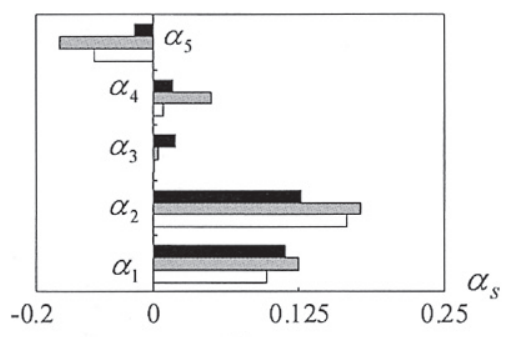

BS1

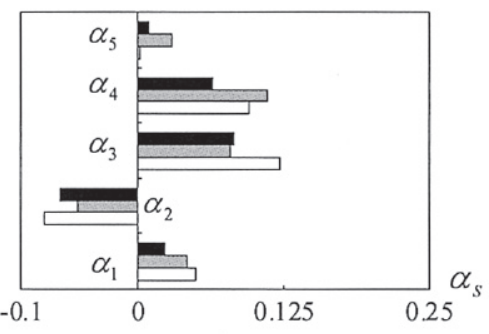

BS3

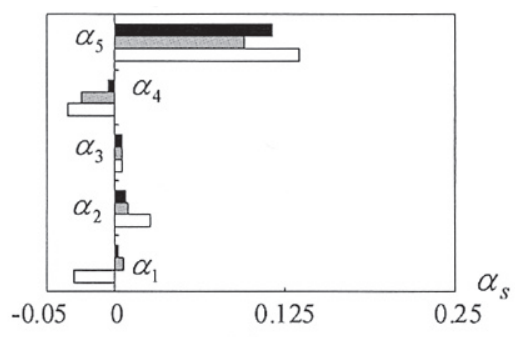

BS5

選択モード1 ロ 選択モード2 ロ 選択モード3

図11 梁端フランジ除去の層剛性低下率
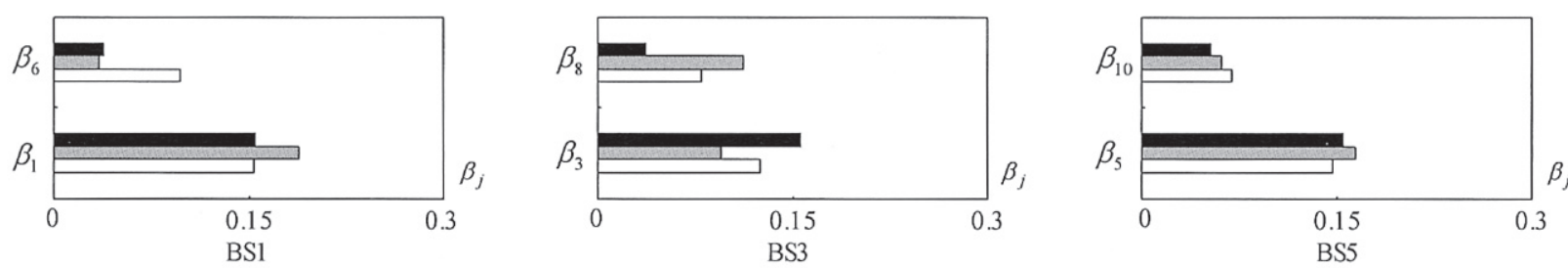

選択モード 1

選択モード 2

選択モード3

図12 梁端フランジ除去の接合部剛性低下率
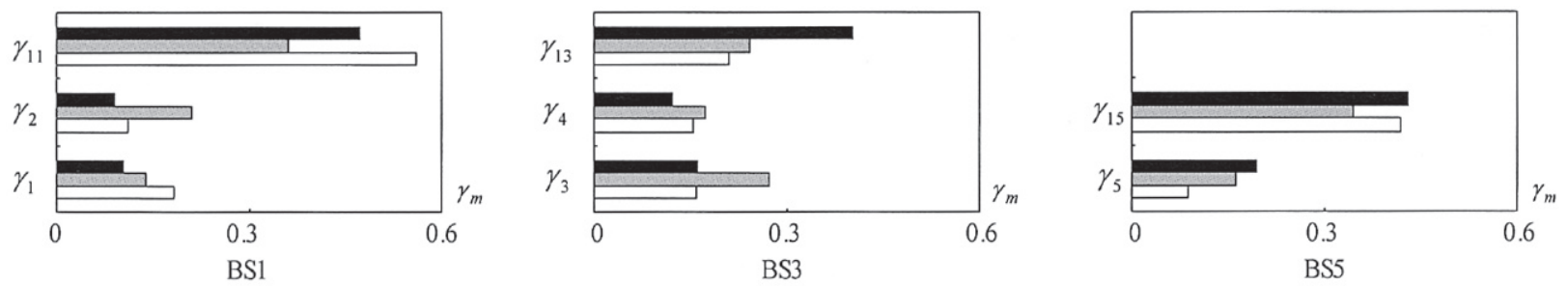

選択モード1

選択モード 2

選択モード 3

図13 梁端フランジ除去の部材剛性低下率

モード形変化率の採用モード次数は，表 3 に示すように，それぞれ $\mathrm{BC} 1$ で 1，2，3 次と採用なし， BC3で 1，2，3，4 次と 3 次， $\mathrm{BC} 5$ で1，2，3，4 次と 3，4 次となった。

選択モード1〜3 を用いて同定した層剛性低下率を図16に示す。 選択モード 1 〜 3 とに, $\mathrm{BC} 1$ では 1 層と 2 層, $\mathrm{BC} 3$ では 3 層と 4 層，BC5では 5 層が損傷したと特定できる。したがって，損傷接合

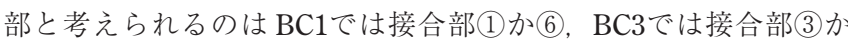
(8)，BC5では接合部(5)か10のいずれかになる。

集約回転ばね付きフレームモデルにより同定した接合部剛性低下 率を図17に示す。選択モード 3 は, $\mathrm{BC} 1$ で接合部(1), BC3で接合部
(3)，BC5で接合部(5)が損傷したと明確に判別できるが，選択モード 1 は BC3で，選択モード 2 は $\mathrm{BC} 1$ と $\mathrm{BC} 3$ で損傷接合部を判別しづ らい。

材端回転ばね付きフレームモデルにより同定した部材剛性低下率 を図18に示す。選択モード 3 は, BC1で部材 $11, \mathrm{BS} 3$ で部材 13 , BC5で部材15が損傷したと明確に判別できるが, 選択モード 1 は BC3で判別しづらく, 選択モード 2 は BC3でまったく判別できない。 選択モード 3 の部材剛性低下率は $0.25 \sim 0.35$ と同定されており, ば らつきがやや大きくなっている。 

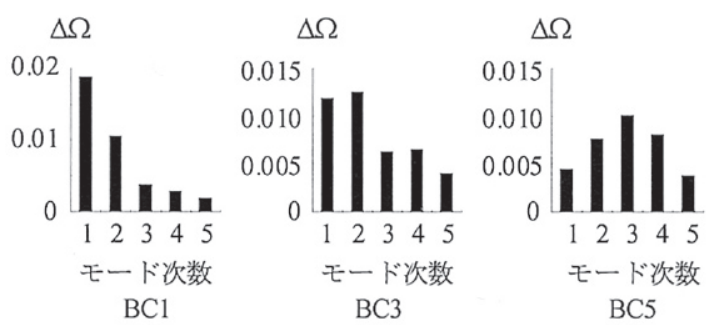

図14 梁端切り欠きの固有振動数変化率
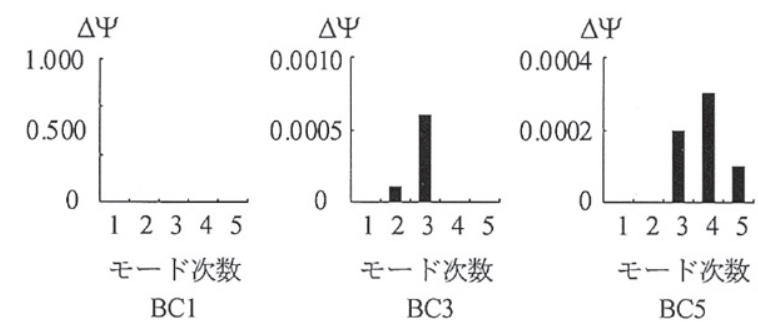

図15 梁端切り欠きのモード形変化率
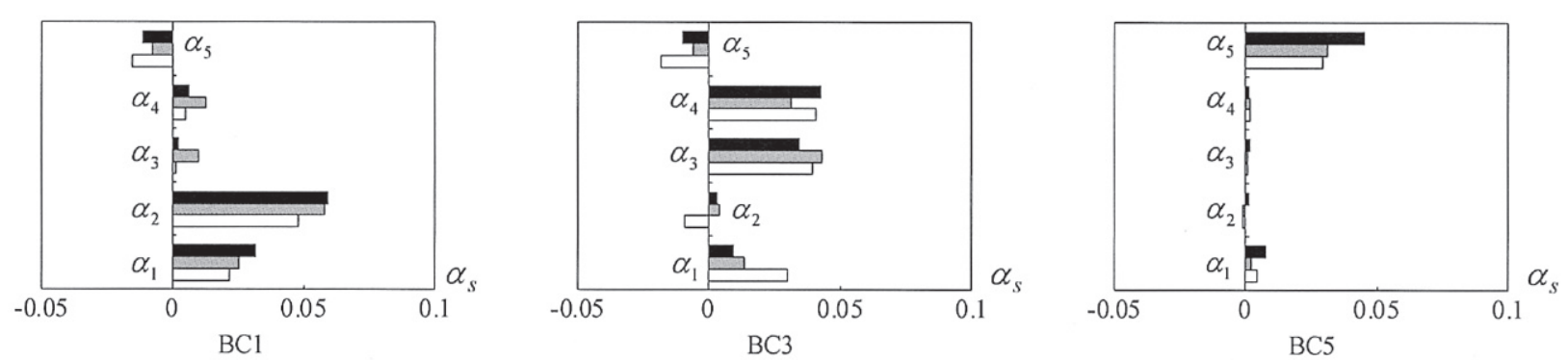

選択モード1 ロ 選択モード2 ロ 選択モード3

図16 梁端切り欠きの層剛性低下率
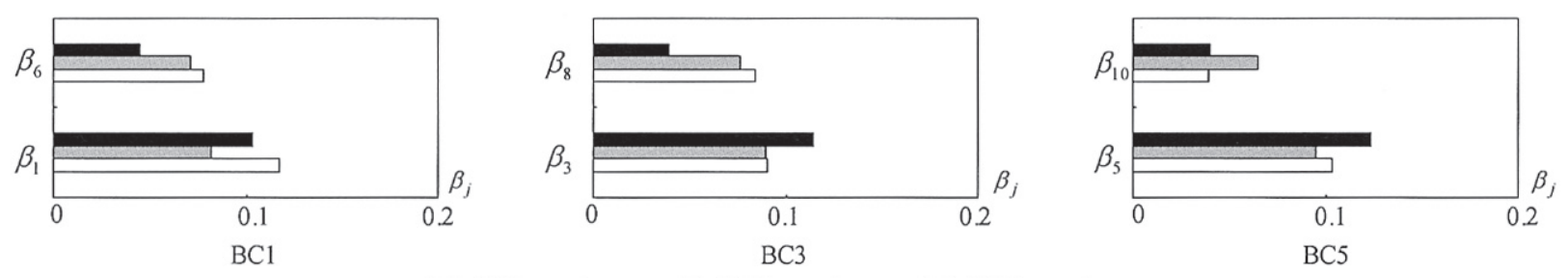

選択モード1 ロ 選択モード2 ロ 選択モード3

図17 梁端切り欠きの接合部剛性低下率
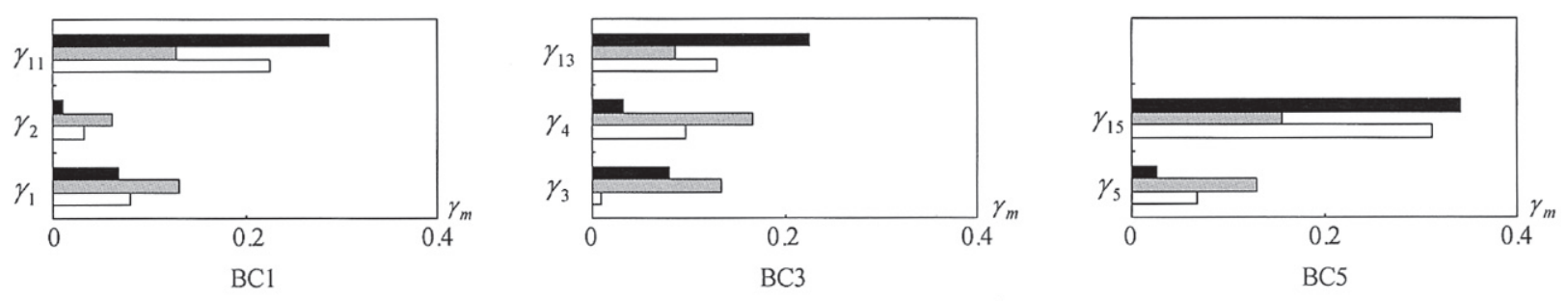

選択モード1

選択モード2

選択モード 3

図18 梁端切り欠きの部材剛性低下率

\section{8 梁端フランジ継手のボルトを緩めた場合の部材損傷検出}

梁端フランジ継手のボルトを 1 層（BB1），5層（BB5）で緩め た場合の層損傷，接合部損傷，および部材損傷を同定する。

ARX モデルにより同定した固有振動数変化率を図19にモード 形変化率を図20に示す。モード形変化率は, BB1では全モードに, また BB5では 4 次以外には有意な変化が見られなかった。選択モー ド 3 において, 固有振動数変化率とモード形変化率の採用モード次 数は，表 3 に示すように，それぞれBB1で1，2，3 次と採用なし， BB5で 1，2，3，4 次と 4 次となった。

選択モード 1 〜 3 を用いて同定した層剛性低下率を図21に示す。
選択モード 1 〜 3 ともに, BB1は 1 層と 2 層, BB5は 5 層が損傷し たとほぼ判別できる。したがって，損傷接合部と考えられるのは BB1では接合部(1)か(6)，BB5では接合部(5)か(10)のいずれかになる。 ただし，損傷程度が軽微なため，前 2 例に比べると精度は落ちてい る。

集約回転ばね付きフレームモデルにより同定した接合部剛性低下 率を図22に示す。選択モード $1 〜 3$ ともに，BB1は接合部(1), BB5 は接合部5が損傷したと判別できる。

材端回転ばね付きフレームモデルにより同定した部材剛性低下率 を図23に示す。選択モード 2 と 3 は BB1で部材 $11, B B 5 て ゙$ 部材 15 が 


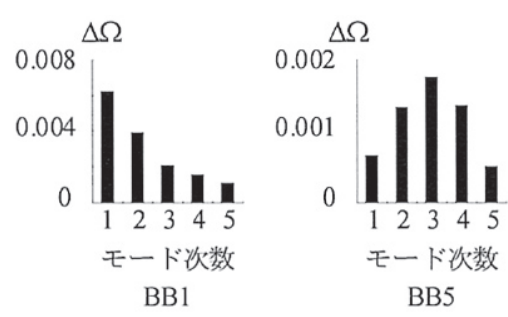

図19＼cjkstart梁ボルト緩めの固有振動数変化率
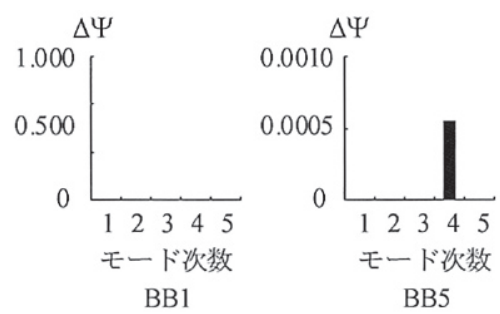

図20＼cjkstart梁ボルト緩めのモード形変化率

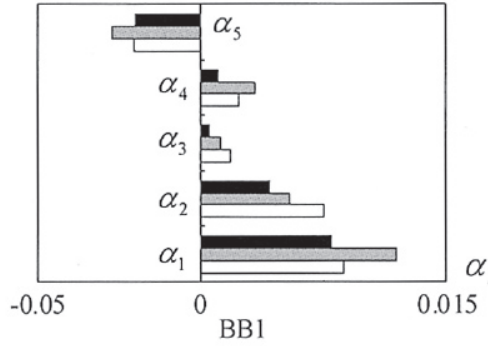

選択モード 1

$\square$ 選択モード2

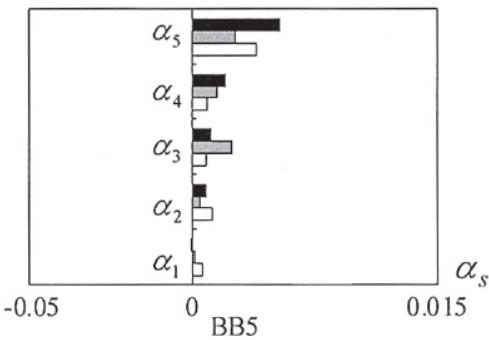

選択モード 3

図21＼cjkstart梁ボルト緩めの層剛性低下率

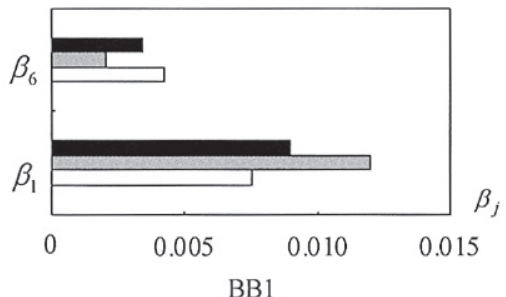

選択モード $1 \quad \square$ 選択モード

図22＼cjkstart梁ボルト緩めの接合部剛性低下率

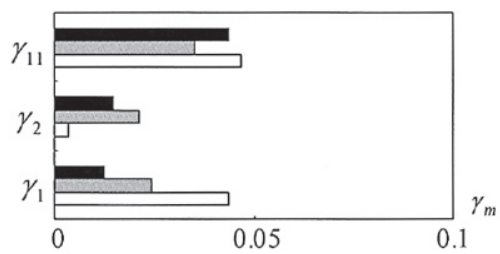

BB1

選択モード 1

選択モード 2

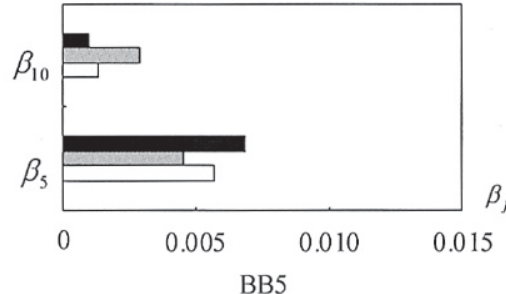

BB5

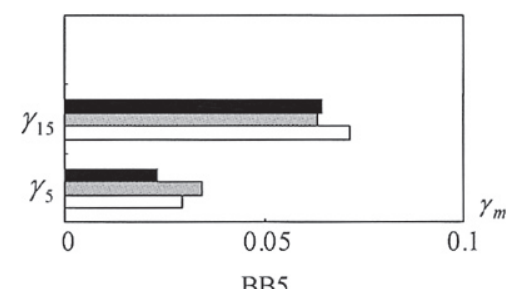

BB5

図23梁ボルト緩めの部材剛性低下率

損傷したと明確に判別できるが，選択モード 1 と 2 は BB1で判別 しづらい。選択モード 3 の部材剛性低下率は，損傷は小さいが 0.05 程度と明確に同定されている。

\section{8. 結び}

少数のセンサを建物内部に配置し，部材レベルの損傷をある程度 検出できるような損傷検出法の開発を目指して，並列モデル同定の 概念を示した。少数の既知情報（モード特性）から多数の部材の損 傷状態を直接検出することは無理があるので，本研究では，既知情 報と未知情報の数のバランスを取りながら, 層損傷, 接合部損傷,
部材損傷と徐々に損傷領域を絞り込む方法を採用した。本手法の有 効性は,まだ単純な純フレーム構造物で検証された段階ではあるが, 基本的な概念は一般的な構造物に対しても適用できると考えられ る。

以下に，本研究の範囲内で得られた知見を要約する。

1 ）材端回転ばね付きフレームモデルとそれを縮約した曲げせん断 モデルを同時に用いることにより, 少数の加速度センサの配置 でも，損傷層の特定，損傷接合部の特定を経て，損傷部材を特 定し，その損傷度を推定ができる可能性がある。

2 ）材端回転ばね付きフレームモデルを集約した曲げせん断モデル 
は, 高次モードでも精度よく固有振動数とモード形を再現する ことができ，せん断型モデルでは層レベルの損傷検出ができな かった場合でも，部材レベルの損傷検出まで可能になった。

3 ）層レベル，接合部レベル，および部材レベルの損傷検出で用い

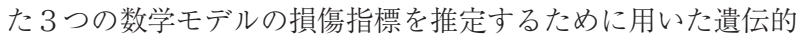
アルゴリズムは，対象とするモード特性を全体として徐々に変 化させながら目的関数を最小化でき，本損傷検出法に適した最 適化手法といえる。

4 ）部材レベルの損傷検出を行う場合, 固有振動数変化率だけでは 情報として十分ではなく，そうかといってモード形変化率に関 する情報をすべて加えても逆に同定精度が落ちるという傾向が 見られた。固有振動数変化率とモード形変化率のうち, 感度の 高いモードのみを選別して同定する方法が最も良い結果を与え た。

5 ) 本研究で用いた数学モデルで検出できる部材損傷は, 梁端ある いは柱頭・柱脚に損傷が集中する場合であり，適用範囲は純フ レーム構造物に限定される。ブレースや壁を含む構造には, さ らに数学モデルの高度化が必要である。

\section{謝辞}

ここで使用した振動台実験のデジタルデータは日米共同構造実験 研究「高知能建築構造システムの開発」（1998～2003年）のセンサ 部会性能モニタリング WG における損傷検出実験の結果を建築研 究所で整理したものである。
いた多層建築物の層損傷検出，日本建築学会構造系論文集，No. 560, pp.93-100, 2002.10

2）濱本卓司, 森田高市, 相馬澄子：逐次最小二乗法による多層建築物の地 震損傷追跡, 日本建築学会構造系論文集, No. 603, pp.39-46, 2005.5

3）濱本卓司，近藤一平：鉛直・水平方向探索を用いた偏心を有する多層建 築物の二段階損傷検出, 日本建築学会構造系論文集, No. 519, pp.21-28, 1999.5

4）濱本卓司, 大浴佳治, 三好敏晴：アクティブ同定手法を用いた多層建築 物の損傷検出，日本建築学会構造系論文集，No. 539，pp.51-56，2001.1

5）圓 幸史朗, 池ヶ谷 靖, 中村 充, 柳瀬 仁：スマートセンサと無線 ネットワークを用いた構造ヘルスモニタリングシステムの開発, 日本地 震工学会論文集，第 7 卷，第 6 号, pp.17-30, 2007.11

6）濱本卓司：建築物の挙動をはかる新しいセンシング技術，建築防災， Vol.378, pp.2-9, 2009.7

7) Doebling, S.W. et al.: Damage Identification and Health Monitoring of Structural and Mechanical Systems from Change in Their Vibration Characteristics: A Literature Review, Los Alamos National Laboratory, LA-1370-MS, 1996

8) Hao, H., Xia, Y.: Vibration-based Damage Detection of Structures by Genetic Algorithm. J. of Computing in Civil Engineering, ASCE, Vol. 16, No. 3, pp.222-229, 2002.

9) Friswell, M.I., Penny, J.E.P., Gravey, S.D. : A Combined Genetic and Eigensensitivity Algorithm for the Location of Damage in Structures, Computers and Structures, 69, pp.547-556, 1998.

10）松本慎也, 春日康博, 藤井大地, 藤谷義信 : 接合部のコストを考虑した 半剛接鉄骨建物の最小コスト解析, 日本建築学会構造系論文集, No. 528 , pp.113-119, 2000.2

11) Saito, T., Mase, S., Morita, K.: A Probabilistic Approach to Structural Damage Estimation, Structural Control and Health Monitoring, 12, pp.283-299, 2005 